\title{
STATUS HUKUM PEREMPUAN MENURUT IBN HUĀZM DAN KEDUDUKANNYA DALAM KOMPILASI HUKUM ISLAM (KHI)
}

\author{
M. Khoirul Hadi al-Asy'ari \\ Alumnus Pasca Sarjana Hukum Islam UIN Sunan Kalijaga Yogyakarta dan \\ Pegiat Hukum Islam Ponpes Baitul Hikmah Krapyak Yogyakarta \\ e-mail: hadiari701@yahoo.com
}

\begin{abstract}
This study based on library research that discusses the legal status of women in the view of Ibn Hāzm. This study intends to answer three important questions; first, how the circumstances of the biography of Ibn Hāzm and socio-historical culture that surrounds his life; second, how the thought of Ibn Hāzm about the legal status of women; third, is there any thought of Ibn Hāzm relevance to the concept of gender in islamic law compilation (KHI). This research is expected to contribute at least in three points of view; first, examine the biography of Ibn Hāzm and educational history and culture surrounding his social life; second, describe Ibn Hāzm's modern thinking with regard to the legal status of women; and third, discover the extent of the relevance of his thinking on gender discourse in KHI. Using istişhāb, Ibn Hazm concludes that women and men have the same high legal status. This thought even beyond the perspective of gender, human rights, multiculturalism, pluralism and democracy that are still not familiar with Indonesian ulama. This is among the arguments that claimed as the reason for the failure of the initiative of KHI Counter Legal Drafting (CLD).
\end{abstract}

Penelitian ini merupakan penelitian kepustakaan yang membahas tentang status hukum perempuan dalam pandangan Ibn Hẫzm. Penelitian ini bermaksud menjawab tiga pertanyaan penting; pertama, bagaimana biografi Ibn Ḥāzm dan kultur sosio-historis yang melingkupi kehidupannya; kedua, bagaimana pemikiran Ibn Hāazzm tentang status hukum perempuan; ketiga, adakah relevansi pemikiran Ibn Hāzm dengan konsep gender dalam Kompilasi Hukum Islam (KHI). Penelitian ini diharapkan memberi kontribusi setidaknya dalam tiga hal; pertama, menelaah biografi dan riwayat pendidikan Ibn Ḥāzm serta kultur sosial yang melingkupinya; kedua, mengetahui pemikiran modern Ibn Hāāzm berkaitan dengan status hukum perempuan; dan ketiga, menemukan sejauhmana relevansi pemikirannya terhadap diskursus gender dalam KHI. Menggunakan metode istișhāb, Ibn H\{azm menyimpulkan bahwa perempuan dan laki-laki mempunyai kedudukan status hukum yang sama tingginya. Pemikiran ini bahkan melampaui perspektif gender, HAM, multikulturalisme, pluralisme, dan demokrasi yang masih belum familiar dengan ulama Indonesia. Inilah diantara argumentasi yang dikalim sebagai alasan gagalnya inisiatif Counter Legal Drafting(CLD) KHI.

Keywords: Ibn Ḥāzm, legal status, gender, Islamic Law Compilation (KHI) 


\section{Pendahuluan}

Al-Qur'an sebagai sumber ajaran Islam mengandung banyak pengetahuan tentang berbagai aspek kehidupan manusia, baik yang bersifat normatif maupun teologis yang menjadi pola hidup (way of life) bagi pemeluknya. Dengan kata lain, pola hidup kaum Muslimin sudah barang tentu didasarkan pada pemahaman mereka terhadap al-Qur'an, baik dengan pemahaman yang bersifat teologis, historis sosiologis, ataupun kombinasi wahyu dengan realitas. ${ }^{1}$ Dengan pemahaman-pemahaman tersebut, makna dan kehadiran seorang Muslim di masyarakat lebih fungsional.

Sejak awal al-Qur'an memang telah mendorong bagi para pembaca dan peminatnya untuk bangkit dan merenung, baik secara intelektual maupun secara kultural, ${ }^{2}$ karena ia hadir di tengah-tengah kaum yang memang tidak bisa membaca dan menulis (ummi). ${ }^{3}$ Dalam memahami al-Qur'an kaum Muslimin sejak generasi pertama telah mengakomodasi berbagai permasalahan yang muncul akibat perkembangan kultur manusia yang senantiasa berubah. Dengan demikian al-Qur'an senantiasa "șāliḥun li kulli zamān wa makān", yang mengandung arti bahwa ajaran al-Qur'an bersifat universal. Oleh karena itu jika dalam al-Qur'an ditengarai terdapat fenomena kontradiktif, maka sesungguhnya hal itu hanya menyangkut pemahaman terhadapnya, bukan esensi yang terdapat di dalamnya.

Status hukum perempuan dalam beberapa pemahaman yang ada cenderung ditempatkan pada posisi yang lebih rendah. Pemahaman-pemahaman tersebut berasal dari masyarakat yang mempunyai budaya patriarkhis, terutama masyarakat Arab. Boleh jadi karena budaya dan pengaruh lingkungan sosiologis tersebut penafsiran-penafsiran ulama klasik menempatkan perempuan dalam status hukum yang "kedua". Penafsiran demikian menjadi

\footnotetext{
${ }^{1}$ Sayyid Muhammad Rasyīd Ridhā, Tafsīr al-Manār (Beirut: Dār al-Ma'ārif, t.th), h. 4 \& 17.

${ }^{2}$ QS. al-'Alaq [96]: 1-5. Lihat juga Khālid Abd al-Raḥmān, Ușūl al-Tafsīr wa Qawāiduh (Beirut: Dār al-Nafs, 1986), h. 32.

${ }^{3}$ Sebagian Masyarakat Arab menjelang kehadiran Nabi Muhammad adalah masyarakat yang disebut dengan Jāhiliyyah. Mayarakat ini nyaris tidak memiliki sesuatu yang layak disebut sebagai ilmu pengetahuan. Lihat: Aḥmad Amīn, Daw' al-Islām, cetakan 10 (Beirut: Dār al-Kitāb al-'Arabiyyah, 1969), h. 140.
} 
mainstream dan hampir tidak ada penafsiran yang yang berbeda. Dari yang sedikit itu adalah cara pembacaan Ibn Ḥāzm yang menempatkan status hukum perempuan sama dengan status hukum laki-laki. Pemikiran Ibn Ḥāzm ini menarik karena ia merupakan mujtahid fatwa dalam mazhab yang terkenal sangat tekstualis yaitu mazhab al-Ẓāhiri. Seorang dengan latar belakang mazhab yang sangat ketat, justru menghasilkan pandangan yang sangat liberal dalam konteks kekinian. Tulisan berikut ini mencoba melakukan kajian dan pembacaan ulang terhadap konsep Ibn Hāāzm serta menilik lebih dalam kajian serta metodologi yang digunakannya hingga sampai pada kesimpulan yang menempatkan status perempuan sama dengan status laki-laki di ranah publik. Permasalahan yang hendak digali jawabnya meliputi tiga hal sebagai berikut: 1) Bagaimana biografi Ibn Ḥāzm dan kultur sosio-historis yang melingkupi kehidupannya?2) Bagaimana pemikiran Ibn Hāzm tentang status hukum perempuan? 3) Adakah relevansi pemikiran Ibn Ḥāzm dengan konsep gender dalam Kompilasi Hukum Islam (KHI)?

\section{Biografi Ibnu Ḥāzm}

Ibn Hāzm lahir pada hari terakhir bulan Ramadhan tahun 384 H/ 994 M di Manta Lisyam (Cordoba). ${ }^{4}$ Nama lengkap beliau adalah Abū Muhammad 'Alī bin Aḥmad bin Sa'îd bin Hâazm bin Ghālib bin Șālih bin Sufyān bin Yazìd. Ibn Ḥāzm merupakan keturunan Persia. Kakeknya, Yazīd berkebangsaan Persia yang dibebaskan oleh Yazīd bin Abi Sufyān al-Umawi.5 Ayahnya, Aḥmad bin Sa'îd, termasuk golongan orang cerdas yang memperoleh kemuliaan di bidang ilmu dan kebudayaan. Karena kecerdasannya itulah, ia merasa heran terhadap orang yang kacau dalam perkataannya. Ia berkata: "Sungguh saya heran terhadap orang yang kacau balau dalam khițabah (pidato)-nya, atau tidak tepat dalam penulisannya. Karenanya, jika orang tersebut ragu dalam sesuatu, ia harus meninggalkannya dan berpindah pada hal yang tidak meragukannya, karena sesungguhnya kalām lebih luas daripada ini."6

\footnotetext{
${ }^{4}$ Abd al-Lațịf Shararah, Ibn Ḥāzm Rãid al-Fikr al-'Ilmi (t.t.p.: al-Maktab al-Tijārī, t.t.), h. 35.

5Ibid, h. 36.

6al-Hamidi,Jahwah al-Muqtabis (t.tp.: Dār al-Qawmiyyah, 1966), h. 126.
} 
Kehidupan keluarga Ibn Ḥāzm yang berbahagia dan berkecukupan ini tidak berlangsung lama. Ketika ayahnya menjabat sebagai salah seorang menteri pada akhir pemerintahan Umayyah yang pertama di Andalūsia bencana menimpanya bersamaan dengan terjadinya pergantian penguasa. Sebagai seorang pemangku kekuasaan khalīfah Umawiyyah, Hisyām Abu Manșūr al-'Āmiri tidak dapat berbuat apa-apa. Khalifah tidak lebih dari seorang boneka. Di sana-sini sering terjadi pemberontakan, yang dimulai sejak tahun 398 H. Para pemberontak menyerang, merampok dan membuat porak poranda Cordoba Barat. Akibatnya, terjadi pengungsian besar-besaran. Keluarga Ibn Hāzm terpaksa mengungsi ke kediaman lamanya di Cordoba Timur, tepatnya desa Bilat Magis pada tahun 399 H. Dalam kondisi yang tidak menentu inilah, Aḥmad, ayah Ibn Ḥāzm dipanggil ke hadirat Allah pada tahun $402 \mathrm{H}^{7}$

Dalam bukunya Ṭawq al-Hamāmah, Ibn Ḥāzm secara panjang lebar mengungkap otobiografinya. Ibn Ḥāzm memaparkan bahwa ia mula-mula memperoleh pendidikan dasarnya dari para jawari, perempuan-perempuan yang melayani keluarga ayahnya. Dari mereka Ibn Ḥāzm belajar membaca, menulis, puisi, dan menghapal al-Qur'an. Ibn Ḥāzm berada dalam bimbingan mereka hingga ia menginjak usia menjelang dewasa. ${ }^{8}$

Memasuki usia dewasa, Ibn Ḥāzm diserahkan oleh ayahnya kepada seorang ulama yang 'âlim, zāhid dan wira'ī, yaitu Abū al-Ḥusaini bin 'Alī al-Fārisi. Dalam bimbingannya Ibn Ḥāzm diperkenalkan dengan banyak ulama dalam berbagai disiplin ilmu. Ibn Ḥāzm pernah diajak menghadiri majlis ta'lìm Abū Qāsim 'Abdurraḥmān al-Azdi. Dari sinilah bermula pembentukan kepribadian Ibn Hâazm yang walau terkenal tajam dan pedas lisannya, namun memiliki rasa keikhlasan yang tinggi dan konsisten antara ilmu dan amal. Semua ini tidak bisa dilepaskan dari jasa ayahnya yang sangat memperhatikan pendidikannya. Bahkan Abū Lailā menyatakan bahwa ayahnya punya peran yang besar dalam pembentukan karakter Ibn Ḥāzm. Sebab ia berperan sebagai ayah, ibu sekaligus guru bagi anaknya. ${ }^{9}$

\footnotetext{
${ }^{7}$ Abu Zahrah, Ibn Hāzm (Kairo: Mațba'ah al-Yusūfiyyah, 1931), h. 29-30.

8Ibid,, h. 27.

${ }^{9}$ Abū Lailā, Life and Work of Ibn Ḥ̂̄zm, h. 76.
} 
Ketenteraman Cordoba yang tidak kunjung tiba memaksa keluarga Ibn Ḥāzm berhijrah ke Almeria, sebuah kota yang berada di tepi pantai yang merupakan kota kedua sesudah Cordoba. Kota ini didiami oleh penduduk yang mayoritas adalah pendukung Abū Manșūr al-Āmiri. Di Almeria Ibn Ḥāzm benar-benar menikmati ketenangan dan ketentraman. Waktunya lebih banyak dihabiskan untuk membaca, menulis dan berdiskusi dengan para ulama dan cendekiawan setempat. Aktivitas intelektual Ibn Ḥāzm semakin menanjak dan semakin matang. Namun pada tahun $407 \mathrm{H}$ keadaan tersebut berubah ketika ia dan temannya, Muhammad bin Ishāq dituduh membuat gerakan bawah tanah untuk mengibarkan bendera Umayyah. Karena itu, pemerintahan 'Alawiyyīn yang berkuasa menangkap dan memenjarakan keduanya. Atas jasa pejabat yang loyal pada Abū Manșūr keduanya dibebaskan untuk kemudian diserahkan kepada salah seorang sahabatnya seorang ulama yang bernama Abū al-Qāsim 'Abdullāh bin Hudail yang lebih dikenal dengan sebutan Ibn alMuqaffal. Keduanya menjadi tamu istimewa ulama itu selama sebulan setelah sebelumnya meringkuk di penjara dalam waktu yang sama. Sesudah itu keduanya berangkat menuju Valencia untuk mendukung al-Murtaḍā dalam rangka mengibarkan bendera Umayyah kembali.10

Dalam pemerintahan al-Murtạ̣ā, Ibn Hāāzm diangkat sebagai salah seorang menteri. Namun, keadaan itu tidak berjalan lama. Kekuatan 'Alawiyyīn yang besar selalu mengancam hingga akhirnya terjadi pertempuran di Granada yang menewaskan al-Murtaḍā. Para pengikut al-Murtaḍā yang masih hidup ditawan termasuk Ibn Hazm. Setelah bebas Ibn Ḥāzm kembali ke Cordoba yang telah ditinggalkannya selama 6 tahun. Di Cordoba Ibn Ḥāzm kembali menekuni bidang yang sangat diminatinya yaitu ilmu pengetahuan. Diskusi dan perjalanan ilmiah selalu ia lakukan bila ada kesempatan. Perubahan politik di Cordoba rupanya menarik Ibn Hāzm untuk terjun ke dalamnya. Perubahan itu terjadi ketika penduduk Andalusia menurunkan penguasa 'alawiyyin secara paksa dan kemudian mengangkat keturunan umayyah yaitu Abdurraḥmān bin Hisyām bin Abdul Jabbār sebagai khalīfah.

10Ibid., h. 41. 
Dalam pemerintahan ini Ibn Ḥāzm diangkat sebagai seorang menteri. Namun oleh karena usianya yang masih belia, khaliffah baru ini selalu curiga kepada orang yang ada di sekitarnya. Ia dengan semena-mena memecat siapa saja yang dikehendakinya. Karena itu, penduduk Cordoba memberontak dan berhasil membunuhnya setelah sempat memerintah selama dua bulan, sedangkan yang masih hidup ditawan termasuk Ibn Ḥāzm. Sejarah tidak mencatat kapan Ibn Ḥāzm dibebaskan. Disinyalir ia dibebaskan tidak lama sesudah itu. ${ }^{11}$

Sesudah peristiwa itu Ibn Ḥāzm bersikeras untuk menekuni ilmu tanpa menengok lagi pada kehidupan politik. Perjalanan ilmiah ia lakukan hampir ke seantero Andalūsia. Ia sering menetap di suatu kota dalam waktu yang lama untuk menyebarkan pemikirannya. Biasanya sesudah menulis sebuah buku, Ibn Ḥāzm lantas menyebarkannya ke berbagai daerah. Di Murcia, Ibn Ḥāzm memperoleh pengikut yang sangat besar jumlahnya, sebab penguasa Murcia saat itu adalah kawan dekat Ibn Ḥāzm yaitu Ibn Rasyīq. Namun sesudah wafatnya Ibn Rasyīq lambat laun pengikut Ibn Hazm semakin berkurang. Hal ini disebabkan kehadiran al-Bāji, seorang ulama yang menimba ilmu dari dunia Timur. Tidak henti-hentinya, al-Bāji membantah dan membantai pendapat-pendapat Ibn Ḥāzm. Oleh karena kalah pamor akhirnya Ibn Ḥāzm meninggalkan Murcia. ${ }^{12}$ Penderitaan tragis menimpa Ibn Hāzm ketika menetap di Sevilla. Dengan mata kepalanya Ibn Ḥāzm menyaksikan pembakaran buku-bukunya oleh penguasa Sevilla, al-Mu'tadīd yang memerintah pada tahun 439-464 H. ${ }^{13}$

Pembakaran ini bisa dimengerti, sebab Ibn Ḥāzm merupakan pemikir Muslim yang merdeka, mandiri dan berani menentang arus masanya. Kehidupan keluarganya yang serba kecukupan dalam harta, kedudukan dan kehormatan membuatnya tidak tergantung kepada orang lain. Kemandiriannya mengantarkannya sebagai orang yang merdeka dalam cara berpikir, berkata dan berperilaku. Ia tidak membenarkan dirinya mengikuti pendapat

\footnotetext{
${ }^{11}$ Ibid.

12Ibid., h. 47.

13Ibid., h. 49.
} 
orang lain yang tidak sesuai dengan keyakinannya, apapun alasannya. Karena itu, wajar bila kemudian Ibn Ḥāzm sering terlibat perdebatan sengit dengan lawan bicaranya, khususnya kalangan fuqaha. Ibn Ḥāzm terkenal sangat keras, padas dan tajam lisan dan penanya. Ketika berdebat Ibn Ḥāzm sering menggunakan kata yang sangat menyinggung perasaan dalam bicaranya. Misalnya kata-kata jahl, hamq dan lain-lain. Dari sini bisa dipahami mengapa mereka tidak menyukai Ibn Hāazm yang ujung-ujungnya adalah pembakaran terhadap sebagian besar bukunya. ${ }^{14}$

Saat itu mayoritas penduduk Andalūsia bermazhab pada salah satu dari empat mazhab besar, Māliki. Siapa saja yang keluar dari salah satu mazhab besar dipandang telah keluar dari jalan yang benar. Di sisi lain latar belakang Ibn Ḥāzm menjadikannya sebagai orang yang benar-benar merdeka dalam berpikir dan bertindak. Pendapat siapapun yang tidak sesuai dengan kebenaran yang diyakininya berasal dari Allah, maka ia tinggalkan, tidak peduli apakah ia seorang sahabat, tabi'in atau ulama. Tidaklah sulit menemukan tulisan Ibn Hāzm yang membantah dan menghujat mereka. Atas dasar inilah hati para ulama terasa semakin sesak. Akhirnya mereka memohon kepada penguasa Sevilla. Al-Mu'tadīd sendiri punya kepentingan politik untuk menyingkirkan Ibn Ḥāzm, lantaran latar belakang Ibn Ḥāzm adalah pendukung utama Banī Umayyah yang sewaktu-waktu siap meruntuhkan dirinya. Karenanya, permohonan para ulama itu bagai pucuk dicinta ulam pun tiba. Tanpa basa-basi al-Mu'tadīd memerintahkan agar kitab-kitab Ibn Ḥāzm dibakar. Sesungguhnya tindakan tersebut telah melampaui batas keinginan para ulama. Al-Mu'tadīd sebenarnya cukup menghentikan langkah Ibn Ḥāzm dengan mengasingkannya ke wilayah lain. Namun yang jelas motif politis lebih mendominasi pada tindakan yang dilakukan penguasa Sevilla ini. Tindakan yang bertujuan menegakkan syi'ar agama telah disusupi oleh hawa nafsu dan kepentingan pribadi. ${ }^{15}$

Akhirnya Ibn Ḥāzm terpaksa meninggalkan Sevilla menuju tempat tinggal para leluhurnya sewaktu pertama kali datang ke Andalūsia, yaitu desa Manta

\footnotetext{
${ }^{14} \mathrm{Abd}$ al-Lațīf Shararah, Ibn Ḥāzm Rāid al-Fikr al-IImi (t.tp.: al-Maktab al-Tijārī, tth.), h. 48 -49.

${ }^{15}$ Abu Zahrah, Ibn Hāzm, h. 52-53.
} 
Lisyam yang jauh dari hiruk pikuk kehidupan kota. Di sini Ibn Ḥāzm semakin berkonsentrasi untuk membaca, menulis dan mendidik penerus perjuangannya. Santri-santri berdatangan dari berbagai penjuru Andalūsia. Tidak sedikit diantaranya yang menjadi ulama-ulama besar, seperti al-Ḥumaidi. ${ }^{16}$ Ibn Ḥāzm sempat beristeri dan beranak pinak. Ibn Ḥāzm memiliki tiga orang anak yang merupakan tokoh-tokoh ulama dan cendekiawan serta penerus perjuangan yang telah dirintisnya. Mereka adalah Abū Rāif' Faḍl, Abū Sulaymān al-Muș'ab dan Abū Salāmah Ya'qūb. Abū Rāfi' adalah seorang ulama yang diperhitungkan karena dianggap paling menguasai ilmu Ibn Ḥāzm. ${ }^{17}$ Ibn Ḥāzm meninggal dunia pada 28 Sya'ban tahun 456 H / 5 April 1064 di Manta Lisyam. ${ }^{18}$

\section{Pemikiran Hukum Islam Ibn Ḥāzm}

Menurut Ibn Hazm sumber hukum Islam ada empat macam, yaitu alQur'an, Hadis șahịḥ, ijmā' dan dalīl.19 Al-Qur'an bagi Ibn Ḥāzm merupakan pesan dan perintah Allah kepada manusia untuk diakui dan dilaksanakan kandungan isinya diriwayatkan secara benar, tertulis dalam mushaf dan wajib dijadikan pedoman. ${ }^{20}$ Hadis șahịḥ sebagai sumber kedua menurut Ibn Ḥāzm bersifat saling melengkapi dengan al-Qur'an. Kedua sumber ini merupakan satu kesatuan yang wajib ditaati. ${ }^{21} \mathrm{Hal}$ ini didasarkan pada firman Allah:

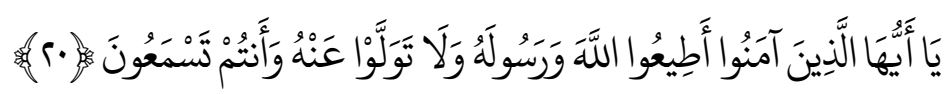

"Hai orang-orang yang beriman, ta'atlah kepada Allah dan Rasul-Nya, dan janganlah kamu berpaling dari-Nya, sedang kamu mendengar (perintahperintah-Nya)."22

Dengan demikian al-Qur'an tidak berperan sebagai pemutus terhadap alSunnah dalam arti untuk diterimanya suatu hadis harus terlebih dahulu di-

\footnotetext{
16Ibid., h. 54.

${ }^{17}$ Ibid.

18Abd al-Lațīf Shararah, Ibn Ḥ̄zzm, h. 50.

19lbn Ḥāzm, al-Iḥkām fi Ușūl al-Aḥkām, jilid I (Mesir: Dār al-Halabi, tth.), h. 70.

20Ibid,, h. 94.

21 Ibid,, h. 95.

${ }^{22}$ QS. al-Anfāl [8]: 20.
} 
hadapkan pada al-Qur'an. Sebaliknya al-Sunnah tidak berlaku sebagai pemutus terhadap al-Qur'an dalam arti al-Sunnah adalah satu-satunya jalan untuk mengerti dan memahami al-Qur'an. Keduanya adalah dua bagian dari wahyu yang saling melengkapi dan tidak terpisah antara satu dengan yang lain..$^{23}$ Sumber hukum yang ketiga adalah ijmā' seluruh umat Islam. Maksudnya adalah ijmā' sahabat, sebab mereka telah menyaksikan tawqï $f$ dari Rasulullah yang merupakan prakondisi terjadinya ijmā'. Juga karena mereka adalah semua orang beriman dan tidak ada manusia beriman selain mereka saat itu. Jadi, ijmā' orang-orang yang seperti ini adalah ijmā' seluruh orang-orang mukmin. Adapun semua ijmā' pada masa sesudah mereka hanyalah ijmā' sebagian orang beriman, bukan ijmā' seluruhnya. ${ }^{24}$

Adapun obyek atau sandaran ijmā' menurut Ibn Ḥāzm adalah berasal dari nașs. Tidak boleh terjadi ijmā' tanpa disandarkan pada naș, sebab usaha manusia dalam rangka menemukan 'illat tidak mungkin sama dikarenakan perbedaan tujuan dan tabiat mereka. ${ }^{25}$ Ibn Hạzm tidak menjelaskan arti ijmā’ secara definitif tetapi membaginya dalam dua bagian. Pertama, segala sesuatu yang tidak diragukan lagi keberadaannya sekalipun hanya oleh seorang Muslim, seperti dua kalimat syahādat, kewajiban menjalankan șalāt lima waktu, keharaman bangkai, darah dan babi, pengakuan terhadap al-Qur'an dan kuantitas zakāt. Kedua, sesuatu yang telah disaksikan oleh seluruh sahabat tentang perilaku Rasulullah atau suatu keyakinan bahwa Rasulullah telah memberitahukan sikap beliau kepada orang-orang yang telah hadir di hadapan beliau. Sumber keempat adalah dalīl, yaitu kesimpulan yang diambil dari pemahaman terhadap dalālah ijmā' dan naṣ.

\section{Status Hukum Perempuan dalam Pandangan Ibnu Ḥāzm}

Salah satu prinsip penting lain yang dipegang oleh Ibn Ḥāzm adalah persamaan kedudukan manusia dalam kaca mata hukum Islam yang berkenaan dengan hak dan kewajiban, kecuali ada naș yang menyatakan pada

\footnotetext{
${ }^{23} \mathrm{Abū}$ Zahrah, Ibn Ḥāzm, h. 298.

24Ibn Hāzm, al-Ihkām, h. 553.

25 Ibid., h. 545.
} 
kasus-kasus tertentu. Hal ini menurutnya adalah sebuah prinsip yang dipakai atau disepakati oleh kaum Muslimin.26 Berdasarkan pandangan itu maka salah satu pemikiran Ibn Hāzm yang terkenal adalah pandangan tentang status hukum seorang perempuan. Ibn Ḥāzm menempatkan status hukum perempuan sama dengan status seorang laki-laki dalam hal hak dan kemanusiaannya. Pemikiran Ibn Ḥāzm itu sangat progresif dan mendekati atau persis sama dengan pemikiran mainstream saat ini.

Berkenaan dengan kepemimpinan laki-laki atas kaum perempuan yang diklaim berdasarkan firman Allah QS. al-Nisā’ [4]:34, ${ }^{27}$ Ibnu Ḥāzm mempunyai perspektif yang berbeda. Menurut Ibn Ḥāzm, ayat tersebut harusnya dipahami dalam konteks kepemimpinan laki-laki dalam keluarga atau pada tempat yang ditinggalinya. Ialah menunaikan kewajiban dan memberi nafkah serta pakaian dan hal-hal lain yang berkaitan dengan kehidupan rumah tangga pada umumnya sebagai bentuk tanggung jawab suami atas istrinya.. ${ }^{28}$ Ayat di atas tidak berbicara tentang kepemimpinan laki-laki yang berkaitan dengan hak, tabiat manusia, atau kemampuan dalam mengurus berbagai hal. Kalau kepemimpinan tersebut diberi makna secara umum, maka akan menggiring terhadap kesimpulan bahwa setiap laki-laki lebih baik dari setiap perempuan. Secara logika pernyatan itu tidak dapat diterima, sebab dalam realitasnya banyak

26Ibid., h. 98.

27Teks ayattersebut:

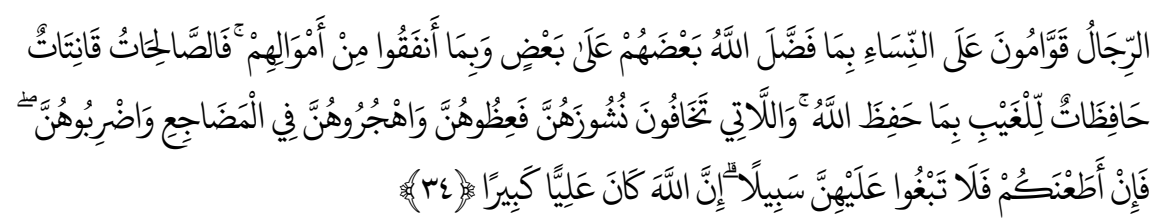

"Kaum laki-laki itu adalah pemimpin bagi kaum perempuan, oleh karena Allah telah melebihkan sebahagian mereka (laki-laki) atas sebahagian yang lain (perempuan), dan karena mereka (lakilaki) telah menafkahkan sebagian dari harta mereka. Sebab itu maka perempuan yang salehah ialah yang taat kepada Allah lagi memelihara diri ketika suaminya tidak ada, oleh karena Allah telah memelihara (mereka). Perempuan-perempuan yang kamu khawatirkan nusyuznya, maka nasihatilah mereka dan pisahkanlah mereka di tempat tidur mereka, dan pukullah mereka. Kemudian jika mereka menaatimu, maka janganlah kamu mencari-cari jalan untuk menyusahkannya. Sesungguhnya Allah Maha Tinggi lagi Maha Besar".

28Ibn Hāzm, al-Muhallā (t.t.p: t.p.. t.th.), h. 110. 
perempuan yang lebih menonjol dan lebih hebat dari pada laki-laki dalam halhal atau bidang-bidang tertentu. Dengan demikian kepemimpian bersifat fungsional, bukan sesuatu yang menetap.

Menurut Ibnu Hāzm, sifat fungsional kepemimpinan berimplikasi kepada peralihannya. Jika suami jatuh dan pailit akibat kemiskinan yang dideranya sedangkan istrinya kaya, maka sang istri wajib menanggung kehidupan suaminya. Dalam hal ini Ibn Ḥāzm menyatakan sebagai berikut:

$$
\begin{aligned}
& \text { فإن عجز الزوج عن نفقة نفسه وامرأته غنية كلفت النفقة عليه ولا ترجع عليه } \\
& \text { بشى من ذلك إن أيسر إلا أن يكون عبدا فنفقته على سيده لا على امرأته، وكذلك إن } \\
& \text { كان للحر ولد أو والد فنفقته على ولده أو والده إلا أن يكونا فقيرين * برهان ذلك قول فئل } \\
& \text { الله عز وجل: (وعلى المولود له رزقهن وكسوتهن بالمعروف لا تصكلف نفس إلا وسعها } \\
& \text { لا تضار والدة بولدها ولا مولود له بولده وعلى الوارث مثل ذلك) * قال على: الزوجة } \\
& \text { وارثة فعليها نفقته بنص القرآن: * قال أبو محمد: ونفقة الزوجة على العبد كما هي على مؤل } \\
& \text { الحر لأن الله تعالى إذ أوجب على لسان رسوله صلى الله عليه وسلم (نفقة النساء } \\
& \text { وكسوتهن على أزواجهن لم يخص حرا من عبد وإذ قال الله تعالى: (وآتوا النساء } \\
& \text { صدقاتهن نحلة) ولم يخص تعالى حرا من عبد وما كان ربك نسيا.29 }
\end{aligned}
$$

${ }^{29} \mathrm{Ibid}$, h. 254. Arti statemen Ibn Ḥāzm itu adalah sebagai berikut.

"Jika suami tidak mampu menafkahi dirinya sendiri, sedangkan istrinya kaya, maka istri dibebani nafkah suaminya, ia tidak boleh meminta kembali, ia tidak boleh meminta kembali sesuatu dari nafkah itu, jika suami telah mampu kembali, kecuali suami adalah seorang hamba sahaya, maka nafkahnya wajib atas tuannya, bukan atas istrinya.Demikian juga jika seseorang yang merdeka memiliki anak atau orang tua, maka nafkahnya wajib atas anaknya atau orang tuanya, kecuali jika keduanya fakir. Dalil atas hal ini adalah firman Allah: "Dan kewajiban ayah memberi makan dan pakaian kepada para ibu dengan cara ma'ruf. Seseorang tidak dibebani melainkan menurut kadar kesanggupannya. Janganlah seorang ibu menderita kesengsaraan karena anaknya dan seorang ayah karena anaknya, dan warispun berkewajiban demikian." Ali berkata: "Seorang istri berhak atas warisan, maka iawajib menanggung nafkah (suami)nya berdasarkan nas al-Qur'an". Abu Muhammad berkata: "Nafkah istri wajib atas (suami yang) hamba sama seperti atas (suami yang) merdeka. Sesungguhnya Allah ketika mewajibkan nafkah melalui (ucapan) Nabi-Nya (nafkah dan pakaian para istri wajib atas suami mereka) tidak mengkhususkan orang merdeka dari hamba. Dan ketika Allah berfirman (berikan kepada wanita-wanita itu maskawin mereka) Allah (pun) tidak mengkhususkan orang merdeka dari hamba, dan Tuhanmu bukanlah pelupa." 
Dasar pandangan Ibn Ḥāzm sebagaimana tersebut adalah firman Allah:

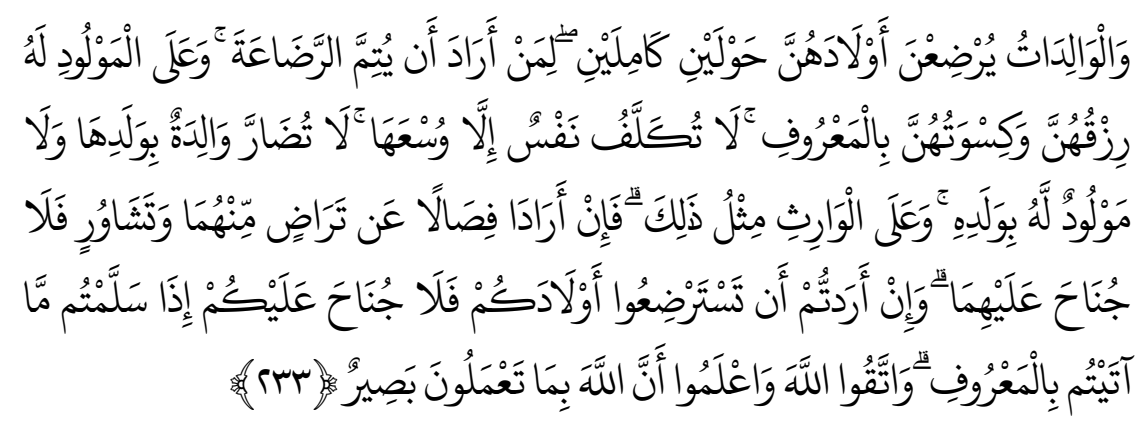

"Para ibu hendaklah menyusukan anak-anaknya selama dua tahun penuh, yaitu bagi yang ingin menyempurnakan penyusuan. Dan kewajiban ayah memberi makan dan pakaian kepada para ibu dengan cara ma'ruf. Seseorang tidak dibebani melainkan menurut kadar kesanggupannya. Janganlah seorang ibu menderita kesengsaraan karena anaknya dan seorang ayah karena anaknya, dan warispun berkewajiban demikian. Apabila keduanya ingin menyapih (sebelum dua tahun) dengan kerelaan keduanya dan permusyawaratan, maka tidak ada dosa atas keduanya. Jika kamu ingin anakmu disusukan oleh orang lain, maka tidak ada dosa bagimu apabila kamu memberikan pembayaran menurut yang patut. Bertakwalah kamu kepada Allah dan ketahuilah bahwa Allah Maha Melihat apa yang kamu kerjakan." 30

Dari ayat tersebut Ibn Ḥāzm menegaskan bahwa nafkah istri wajib atas suami. Suami wajib menafkahi berdasarkan nas al-Qur'an tersebut. Pada dasarnya persoalan yang menyangkut kebutuhan dan kesejahteraan kehidupan rumah tangga merupakan tanggung jawab bersama. Dalam kondisi yang normal, suami sebagai kepala rumah tangga merupakan penanggung jawab rumah tangga. Tetapi dalam kondisi yang tidak normal dimana suami belum bekerja, masih sekolah, atau terkena pemutusan kerja, sementara itu istri mempunyai lahan kerja dan harta serta penghasilan yang cukup, maka kewajiban tersebut beralih ke pundak sang istri. Peralihan ini hanya berpindah selama suami masih belum bisa menafkahi istrinya secara normal. Jika kondisi kembali membaik maka suami berkewajiban kembali untuk menafkahi istrinya kembali seperti sedia kala.

Jika diperhatikan dengan seksama maka pemikiran Ibn Hāzm ini cukup kontroversial. Seorang istri tidak berhak menuntut cerai suaminya di pe-

${ }^{30}$ QS. al-Baqarah [2]: 233. 
ngadilan dengan alasan nafkah. Ia juga tidak boleh menghalangi hak suaminya atas dirinya itu, karena Allah tidak membebaninya kecuali berdasarkan atau sebatas kemampuannya. ${ }^{31}$ Bagaimana mungkin seorang suami dibebani sesuatu yang di luar kemampuan dan kesanggupannya? Dalam kondisi demikian secara otomatis kewajiban suami gugur dan kewajiban tersebut akan kembali seperti semula jika kondisi suami sudah normal dalam artian sudah dapat menafkahi istrinya kembali. Jika dua pasangan tersebut termasuk orang yang kekurangan maka dapat mengambil harta bagian dari orang miskin yang ada di Baytul Mãl. Pendapat Ibn Hāazm ini, mirip dengan pendapat kalangan hanafiah. Berbeda dengan mereka, jumhūr ulama dari mazhab māliki, mazhab syāfi'î, dan mazhab hanbalī memberikan peluang bagi si istri untuk meminta cerai dari suaminya karena sang suami tidak mampu menafkahi istrinya lagi. ${ }^{32}$

Berpijak pada pemikiran tersebut Ibn Ḥāzm memperbolehkan kaum perempuan memegang jabatan hakim secara mutlak ${ }^{33}$ dan jabatan-jabatan lain selain khalifah selama ia mempunyai kemampuan untuk melaksanakan jabatan tersebut dengan baik. Terkait kekuasaan kehakiman Ibn Hāzm menyatakan adanya sejarah seorang ulama perempuan bernama Tsumala Qaramana yang menjabat sebagai Qadi Mazalim di mana majlisnya banyak dihadiri oleh para hakim dan fuqaha. Menurut Tsulama Qaramana, Umar Bin Khațāāb pernah mengangkat Syifä' al-'Adawiyyah sebagai pejabat kepala pasar karena dia sangat ahli dalam bidang tersebut. ${ }^{34}$

Terhadap Hadis Nabi yang banyak diklaim sebagai larangan wanita menjadi pemimpin Ibn Ḥāzm mempunyai penilaian yang berbeda. Dalam pandangan Ibn Ḥāzm, sabda Nabi tersebut ${ }^{35}$ hanya pada wilayah kekhalīfahan,

31 Ibid., h. 253, 254, 257.

${ }^{32} \mathrm{Abū}$ Zahrah, Ibn Hāzm, h. 461-462.

33Ibn Ḥāzm, Al-Muhallā, juz VIII, h. 527.

34Ibn Ḥāzm, Risālāt Naqțal-Arūsfi Tawārikh al-Khulafā' (t.tp, t.th.) h. 98.

35Ibn Hāzm, al-Muhallā, VII, h. 528. Lihat pula Al-Nasāì, Sunan Al-Nasāi', jilid VIII (Beirūt: Dār alFikr, 1980), h. 227. Teks hadis dimaksud adalah sebagai berikut.

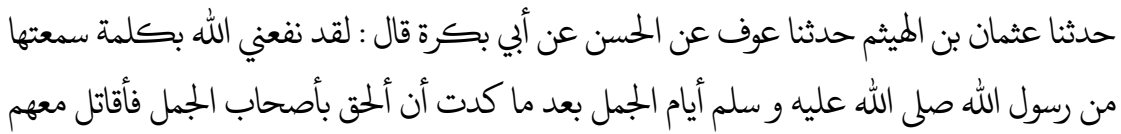


sedangkan dalam hal lainnya tidak. Pandangan Ibn Ḥāzm itu sejalan dengan pandangan Ibn Jarīr al-Ṭabarī, hanya saja landasan yang digunakan Ibn Ḥāzm itu berbeda secara hukum dengan dalil yang digunakannya. Ibn Ḥāzm bertumpu pada tidak adanya dalil yang melarang perempuan untuk menduduki jabatan selain khalīfah, termasuk jabatan sebagai hakim. Sedangkan Ibn Jarīr al-Ṭabarī menyatakan kebolehan perempuan sebagai hakim di bidang selain hudūd dan qiṣaṣ. Adapun tiga imam mazhab lainnya, yaitu: Mālik, Syāfi'î dan Hambalī melarangnya secara mutlak karena berdasarkan kemutlakan hadis di atas. $^{36}$

Pandangan Ibn Ḥāzm tersebut kiranya cukup relevan dengan kondisi sekarang. Di dunia modern ini perempuan merupakan anggota masyarakat yang juga harus mengambil peran yang baik dan tepat dalam mendukung pemberdayaan perempuan, khususnya dalam bidang ekonomi, politik dan pendidikan. Pada dasarnya jabatan apa saja tidak mempunyai jenis kelamin, jadi perempuan dan laki-laki mempunyai kesempatan yang sama dalam mendudukuki jabatan tersebut. Hanya saja untuk jabatan khalifah tidak terbuka bagi perempuan, sedangkan jabatan di luar khalifah cukup terbuka dan perempuan boleh menjabat pada ranah tersebut karena indikasi nașs yang melarang tidak ada. Tidak adanya nas yang melarang itu sesuai dengan dalīl istiṣhāb yang biasa digunakan oleh Ibn Ḥāzm dalam berijtihad.

Menurut Ibn Hāāzm, kesamaan status hukum perempuan dengan laki-laki juga terjadi dalam persoalan kenabian. Hal ini pernah menjadi topik perdebatan yang sengit di kalangan ulama Cordoba pada masa hidupnya dan menimbulkan sikap yang pro dan kontra di antara mereka. Sebagian dari

$$
\text { يفلح قوم ولوا أمرهم امرأة). }
$$

Artinya: Telah menceritakan kepada kami Uthmān bin Haytām, telah menceritakan kepada kami 'Awf, dari Hasan, dari Abī Bakrah berkata: sesungguhnya aku telah mendapatkan manfaat dari pernyataan yang aku dengar dari Rasūlullāh SAW pada saat Perang Jamal ........ ketika sampai kepada Rasūlullāh SAW berita bahwa orang-orang Persia telah mengangkat anak perempuan Raja Kisrā sebagai penguasa mereka, maka beliau bersabda, "tidak akan beruntung suatu kaum yang menyerahkan urusannya kepada perempuan".

36Muhammad Salām Madkūr, al-Qaḍā'fi al-Islām (Beirūt: Dāral-Nahḍah al-'Arabiyyah, tth.), h. 38. 
mereka ada yang menolak dan sebagian lain berpendapat tentang adanya Nabi diantara kaum perempuan. Sebagian ulama lain mengambil sikap tawaqquf. Ibn Ḥāzm sendiri termasuk kelompok yang menyatakan bahwa ada Nabi diantara para perempuan (Nabi perempuan). Pandangan kelompok yang pertama didasarkan pada beberapa firman Allah berikut ini:

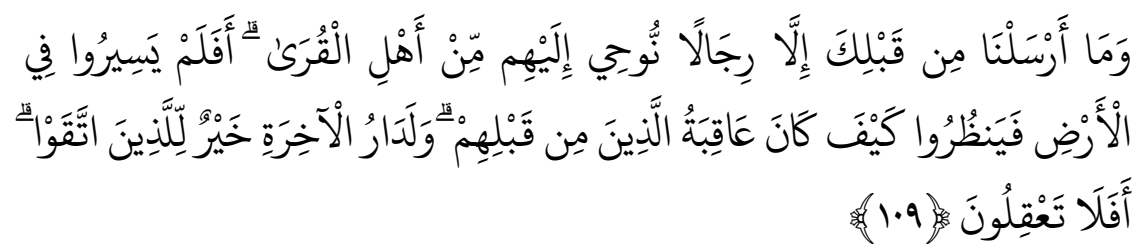

Kami tidak mengutus sebelum kamu, melainkan orang laki-laki yang Kami berikan wahyu kepadanya diantara penduduk negeri. Maka tidakkah mereka bepergian di muka bumi lalu melihat bagaimana kesudahan orang-orang sebelum mereka (yang mendustakan Rasūl) dan Sesungguhnya kampung akhirat adalah lebih baik bagi orang-orang yang bertakwa. Maka tidakkah kamu memikirkannya? ${ }^{37}$

Ayat di atas dalam pandangan Ibn Ḥāzm hanya menyatakan tentang kerasulan dan tidak ada sedikitpun menyatakan tentang kerasulan perempuan. Persoalan yang menjadi bahan perdebatan bukanlah masalah kerasulan, akan tetapi adalah kenabian. Maka dari itu jawaban sebenarnya perlu dicari lagi dari nașs yang lain. Keinginan untuk membuktikan pendapatnya, Ibn Hāzm meneliti naș-naș al-Qur'an dengan pendekatan kebahasaan. Ia kemudian meneliti kata nubuwwat dalam al-Qur'an. Menurutnya, dari segi bahasa, kata nubuwwat diambil dari kata al-inbä' yaitu al-i'lām yang berarti pemberitahuan. Berdasarkan makna itu, maka siapapun yang pernah diberitahu, berdasarkan makna tersebut maka tidak diragukan lagi bahwa ia adalah seorang Nabi. Pemberitahuan ini tidak dalam katagori ilhām Tuhan seperti lebah, bukan pula dugaan atau prasangka yang hakikatnya tidak dapat dipastikan, bukan ramalan, dan bukan pula mimpi. Pemberitahuan itu memang benar-benar wahyu kenabian yang dimaksud oleh Allah. Adapun beberapa wanita yang [21]: 7.

37QS. Yūsuf [2]:109. Dalīl serupa juga terdapat dalam dalam QS. al-Naḥl [16]: 43 dan QS. al-Anbiyā' 
memperoleh pemberitahuan itu, misalnya ibu Nabi Isḥāq (istri Nabi Ibrāhīm), Maryam, dan ‘Āsiyah binti Muzāhim istri Raja Fir'aun. ${ }^{38}$

Berkaitan dengan pemberitahuan yang diterima ibu Nabi Isḥāq, Allah berfirman:

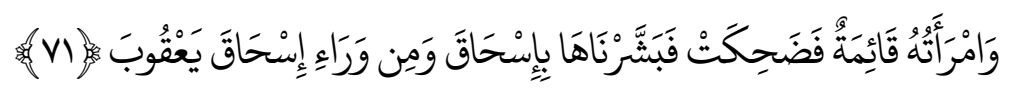

"Dan istrinya berdiri (dibalik tirai) lalu ia tersenyum, Maka Kami sampaikan kepadanya berita gembira tentang (kelahiran) Isḥāq dan dari Isḥāq (akan lahir puteranya) Ya'qūb." 39

Berkenaan dengan pemberitahuan terhadap Maryam, Allah berfirman:

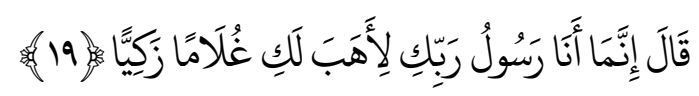

Ia (Jibriil) berkata: "Sesungguhnya aku ini hanyalah seorang utusan Tuhanmu, untuk memberimu seorang anak laki-laki yang suci."40

Sedangkan tentang pemberitahuan terhadap Āsiyah, Nabi bersabda:

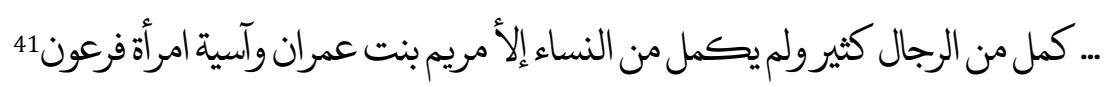

"Banyak yang sempurna dari kaum laki-laki, sedangkan dari kaum kami perempuan tidak ada yang sempurna kecuali Maryam binti Imran dan Āsiyah binti Muzahim istri Fir'aun."

Menurut Ibn Ḥāzm kesempurnaan laki-laki itu hanya terjadi pada para rasūl. Selain rasūl manusia berada pada kekurangsempurnaan, jika dibandingkan dengan mereka. Penyebutan nama perempuan oleh Nabi Muhammad dalam hadis tersebut menunjukkan bahwa mereka itu istimewa dibanding perempuan-perempuan lain, karena faktor kenabian. Dengan membandingkan pendapat tersebut maka, menurut Ibn Ḥāzm, keberadaan Nabi perempuan itu dalilnya lebih kuat dari pada mereka yang menyatakan tidak adanya. Hal ini

\footnotetext{
38 Ibn Hāzm, al-Fișāl fi I-Milal wa I-Ahwā’i wa I-Nihal (t.t.p.: t.p., t.th.), h. 17-18.

${ }^{39}$ QS. Hūd [11]: 71.

${ }^{40}$ QS. Maryam [19]: 19.

41Muhammad bin Ismāil al-Bukhāri, Saḥịh al-Bukhāri dengan tahqīq Muhammad bin Zuhair bin Nașīr (t.t.p.: Dār Ṭawq al-Najāt, Cet. 1, 1422), Hadis no. 3769, jilid 5 h. 29.
} 
karena al-Qur'an nyata-nyata telah menyebut beberapa orang perempuan yang pernah memperoleh wahyu dari Allah melalui perantaraan malaikat, seperti Maryam dan Āsiyah binti Muzāhim istri Fir'aun.

\section{Kedudukan Perempuan dalam Diskursus Gender KHI}

Perkembangan diskursus gender dalam perundang-undangan di Indonesia masih memperlihatkan status hukum perempuan yang belum seimbang dangan pria. Hal ini salah satunya dapat dilihat dari adanya inisiatif Counter Legal Drafting (CLD) atas Kompilasi Hukum Islam (KHI) dalam Hukum Perkawinan yang akhirnya gagal. CLD adalah konsep pembaharuan terhadap KHI yang berprinsipkan pada HAM, pembelaan kesetaraan gender dan keadilan gender, dan menyuarakan pandangan humanis, pluralis dan demokratis. ${ }^{42}$

Pembaharuan dalam bidang hukum perdata Islam ini dirasa penting mengingat KHI adalah produk perundang-undangan yang menjadi hukum materiil dalam Peradilan Agama di Indonesia. Sentralitas KHI diakui dan disadari betul oleh Tim Pengarus Utamaan Gender (TPUG) untuk kemudian memperbaharuinya, karena itu KHI harus dibaca ulang, terutama dari perspektif gender dan pluralisme, HAM dan demokrasi, sehingga tercipta masyarakat yang adil dan demokratis. ${ }^{43}$ Beberapa pasal dalam KHI masih jauh dari prinsip persamaan (al-musāwāh), persaudaraan (al-îkhā), dan keadilan (al-'adl), serta gagasan masyarakat madani seperti pluralisme, kesetaraan gender, HAM, demokrasi, dan egaliterianisme.44

Pada waktu itu suasana patriarkhis masih sangat kental sehingga upaya untuk melakukan amandemen melalui CLD tersebut ditolak. Hal ini berakibat upaya melakukan amandemen terhadap KHI yang masih "memihak" para lakilaki tersebut gagal dilaksanakan. Pada sisi lain, penolakan tersebut terjadi

\footnotetext{
${ }^{42}$ Musdah Mulia, "Menuju Hukum Perkawinan yang Adil, Memberdayakan Perempuan Indonesia", dalam: Sulistyowati Irianto, Perempuan dan Hukum; Menuju Hukum yang Bersperspektif Kesetaraan dan Keadilan (Jakarta: Yayasan Obor Indonesia, 2006), h. 114.

${ }_{43}^{4}$ Tim Pengarus Utamaan Gender Departemen Agama RI, Counter Legal Drafter Kompilasi Hukum Islam (Jakarta: Departemen Agama:2004), h. 3-4.

${ }^{44}$ Ibid, h. 7.
} 
karena pendekatan yang digunakan oleh tim penyusun CLD dianggap lebih menggunakan argumentasi yang tidak berbasis pada hukum Islam, tetapi lebih fokus pada kajian HAM, gender, dan metode dari Barat. Seandainya CLD itu dibalut dengan konsep jaminan sosial yang ditawarkan oleh Ibn Ḥāzm seperti yang di kemukakan diatas mungkin akan bisa lebih diterima karena hukum Islam sebagai basisnya. 45

Dari fenomena tersebut dapat dikemukakan bahwa status hukum perempuan dalam KHI masih sangat jauh dari apa yang pernah disuarakan oleh Ibn Ḥāzm. Oleh karena itu kiranya penting untuk menggali dan menyebarkan serta memunculkan kembali wacana status hukum perempuan dalam pandangan Ibn Ḥāzm. Dengan demikian diharapkan muncul pemahaman yang lebih progresif berkenaan dengan status hukum perempuan di dunia Muslim, dan khususnya di Indonesia.

\section{Kesimpulan}

Penelitian ini menghasilkan tiga kesimpulan penting. Pertama, dalam pandangan Ibn Ḥāzm status hukum perempuan mempunyai kedudukan yang sama tinggi dan sama rata dengan kaum laki-laki. Metode istișhāb yang dilakukan oleh Ibn Hāzm memberikan warna berbeda dalam mengambil istinbāt hukum dari nas al-Qur'an dan Hadis. Pandangan ini sangat menarik dalam konteks corak berpikir Ibn Ḥāzm yang cenderung lebih tekstualis, namun terkesan progresif terhadap ayat-ayat hukum baik dari naș al-Qur'an maupun hadis. Kedua, dari sisi biografi, Ibn Ḥāzm berangkat dari mazhab Syafi'i dan kemudian beralih kepada mazhab al-Zāairi yang cenderung lebih tektualis. Akan tetapi hasil-hasil pemikirannya jika dibaca ulang dalam konteks kekinian, dapat dikategorikan sebagai pemikiran yang moderat. Kesempatan tinggal di Cordoba dan Andalūsia yang merupakan simbol kemajuan dalam berargumen karena langsung berhadapan dengan pemikiran Barat merupakan jawaban analitis dari fenomena ini. Ketiga, jika dilihat bagaimana status hukum per-

\footnotetext{
45Ibid,.. h. 8.
} 
empuan di Indonesia sebagaimana termanifestasikan dalam KHI, maka tawaran/pemikiran Ibn Ḥāzm masih jauh dari kenyataan. Pemikiran Ibn Ḥāzm tentang status hukum perempuan sesungguhnya merupakan wacana baru dalam Islam yang bisa dikatakan melampaui dari apa yang ada dalam pendekatan gender, HAM, dan sebagainya. Namun, antipati kalangan ulama Indonesia terhadap wolrdview dengan pendekatan HAM, gender, multikultural, pluralisme, dan demokrasi merupakan alasan gagalnya CLD KHI pada waktu itu.[a]

\section{DAFTAR PUSTAKA}

Abdur al-Raḥmān, Khālid, Ușūl al-Tafsīr wa Qawāiduh, Beirūt: Dār al-Nafs, 1986.

al-Bukhāri, Muhammad bin Ismāil, Șaḥih al-Bukhāri, tahqīq Muhammad bin Zuhair bin Nașir, t.t.p.: Dār Ṭawq al-Najāt, 1422.

al-Hāmidi,Jadhwah al-Muqtabis, t.t.p.: Dār al-Qawmiyyah, 1966.

Amīn, Aḥmad, Daw' al-Islām, cetakan 10, Beirūt: Dār al-Kitāb al-'Arabiya,1969.

al-Nasāì, Sunan al-Nasā̄i, Jilid VIII, Beirut: Dār al-Fikr, 1980.

Ḥāzm, Ibn, al-Iḥkām fi Ușūl al-Aḥkām, jilid I, Mesir: Dār al-Ḥalabi, t.th.

Ḥāzm, Ibn, al-Muḥallā, t.t.p: Maktabat al-Jamhūriyyah al-'Arabiyyah, 1967.

Ḥāzm, Ibn, al-Fișal fi I-Milal wa I-Ahwā'i wa I-Nihal, t.t.p.t.p., t.th.

Ḥāzm, Ibn, Risālāt Naqț al-Arūs fi Tawārikh al-Khulafä', t.t.p.t.t.p., t.th.

Lailā, Abū, Life and Work of Ibn Ḥāzm, t.t.p.t.p., t.th.

Madkūr, Muhammad Salām, al-Qaḍā' fi al-Islām, Beirūt: Dār al-Nahḍah al'Arabiyyah, t.th.

Mulia, Musdah, "Menuju Hukum Perkawinan yang Adil, Memberdayakan Perempuan Indonesia", dalam Sulistyowati Irianto, Perempuan dan Hukum; Menuju Hukum yang Bersperspektif Kesetaraan dan Keadilan, Jakarta: Yayasan Obor Indonesia, 2006.

Rasyīd Riḍa, Sayyid Muhammad, Tafsīr al-Manār, Beirūt: Dār al-Ma’ārif, t.th. 
M. Khoirul Hadi al-Asy'ari

Shararah, Abd al-Lațîf, Ibn Hāzm Rāid al-Fikr al-'Ilmi, t.t.p.: al-Maktab al-Tijārī, t.th.

Tim Pengarus Utamaan Gender Departemen Agama RI, Counter Legal Drafter Kompilasi Hukum Islam, Jakarta: Departemen Agama, 2004.

Zahrah, Abū, Ibn Hāzm, Kairo: Mațba'ah al-Yusūfiyyah, 1931.

180 || Volume 25, Nomor 2, Oktober 2015

AL-AHKAM — ISSN 0854-4603 